\title{
Simulasi Berbagai Situasi Traffic Flow Dengan Metode Cell Transmission Model
}

\author{
Agung Ferdiana ${ }^{\# 1}$, Putu Harry Gunawan \#2 \\ \# School of Computing, Telkom University \\ Jl. Telekomunikasi No 1, Terusan Buahbatu, West Java, Indonesia, 40257. \\ ${ }^{1}$ agungferdiana@students.telkomuniversity.ac.id \\ 2 phgunawan@telkomuniversity.ac.id
}

\begin{abstract}
This research discusses the application of cell transmission method model to simulate various traffic conditions. This method is relatively simple, and easy to develop. This is a macroscopic approach, which studies the behavior of vehicles not individually, but rather in groups. In this research, the cell transmission method is used to simulate various traffic jam cases cause by road narrowing, road blockage for some time, and the case of merging between the main road with adjacent road. To simulate the merging case, it is necessary to apply the modified cell transmission method. Simulation results show various traffic situations that agree with our daily observations.
\end{abstract}

Keywords: cell transmission model, merge scenario.

\begin{abstract}
Abstrak
Penelitian ini membahas mengenai penerapan metode cell transmission model untuk menyimulasikan berbagai kondisi lalu lintas. Metode ini relatif sederhana sehingga mudah untuk dikembangkan. Pendekatan menggunakan cell transmission model termasuk pendekatan makroskopik yang mana mengkaji perilaku kendaraan tidak secara individu, melainkan secara kelompok. Pada penelitian ini, metode cell transmission model digunakan untuk menyimulasikan berbagai kasus kemacetan lalu lintas yang diakibatkan karena penyempitan jalan, penutupan jalan selama beberapa waktu, dan kasus adanya penggabungan/merge jalan kecil dengan jalan raya. Untuk simulasi kasus adanya penggabungan/merge, perlu diterapkan metode cell transmission model dengan modifikasi. Hasil simulasi dengan metoda cell transmission model menunjukkan berbagai situasi traffic yang sesuai dengan pengamatan kita sehari-hari.
\end{abstract}

Kata Kunci: cell transmission model, merge scenario.

\section{Pendahuluan}

$\mathbf{M}$ ASALAH kemacetan lalu lintas sering ditemui diberbagai negara, termasuk juga di Indonesia. Penyebab kemacetan di Indonesia bisa diakibatkan berbagai faktor seperti, banyaknya penduduk yang mempunyai kendaraan pribadi. Tercatat pada tahun 2013 jumlah kendaraan yang beredar di Indonesia sebesar 104,211 juta unit [6]. Data mencatat bahwa dikota Jakarta $84 \%$ kendaraan yang lalu lalang di jalan raya adalah kendaraan pribadi [9]. Kemudian lambatnya pembangunan infrastruktur (jalan raya, jalan layang, jembatan). Pembangunan jalan tol di Indonesia telah dimulai sejak 26 tahun lalu, namun hingga kini panjang ruas jalan tol baru mencapai $570 \mathrm{~km}$. Indonesia tertinggal dengan negara-negara tetangga dalam pembangunan jalan tol seperti Malaysia mulai pembangunan dari 20 tahun yang lalu, panjang jalan mencapai $1.230 \mathrm{~km}$ dan Cina mencapai $100.000 \mathrm{~km}$ [8]. Masih banyak penyebab kemacetan lainnya seperti kondisi jalan yang rusak sehingga ruas jalan yang dilewati semakin sempit, penggabungan jalan gang kecil dengan jalan utama dan lain-lain [1]. 
Agung Ferdiana et.al.

Interaksi kendaraan dengan kendaraan lainnya juga dapat mempengaruhi arus lalu lintas, dan bisa menimbulkan kemacetan di jalan raya. Sehingga, kita perlu untuk mempelajari tentang traffic fluks agar dapat berprilaku bijak untuk mengurangi atau tidak menyebabkan kemacetan di jalan raya. Traffic fluks adalah banyaknya kendaraan yang melintasi suatu titik pada jalan dengan interval waktu dan diukur dalam satuan kendaraan persatuan waktu [5]. Kajian mengenai traffic flow terbagi menjadi dua yaitu pendekatan microscopic dan pendekatan macroscopic. pendekatan microscopic terjadi saat melihat suatu pergerakan kendaraan terhadap kendaraan lainnya dalam arus lalu lintas dan pendekatan macroscopic yaitu perilaku kelompok kendaraan pada ruas jalan [7]. Pendekatan yang akan digunakan disini adalah pendekatan macroscopic.

Permasalahan: mengkaji penerapan metode CTM untuk simulasi aliran lalu lintas. Beberapa fenomena lalu lintas akan di simulasikan.

Pada penelitian ini menggunakan metode yang sesuai untuk kemacetan pada lalu lintas. Cell transmission model merupakan metode yang pas untuk penelitian ini, karena metode ini dapat menyimulasikan berbagai macam kemacetan lalu lintas di jalan raya. CTM mempunyai persamaan awal seperti:

$$
n_{i+1}(t+1)=n_{i}(t)
$$

Dengan $n_{i}(t)$ sebagai jumlah kendaraan yang berada pada cell $i$ pada waktu $t$. Persamaan (1) sebagai dasar untuk menyelesaikan permasalahan pada penelitian ini. Dalam penelitian ini salah satu permasalahan yang akan dibahas adalah simulasi suatu ruas jalan raya yang mana pada suatu titik terdapat penggabungan jalan kecil dengan jalan raya, sebagai ilustrasi dapat dilihat pada Gambar 1.

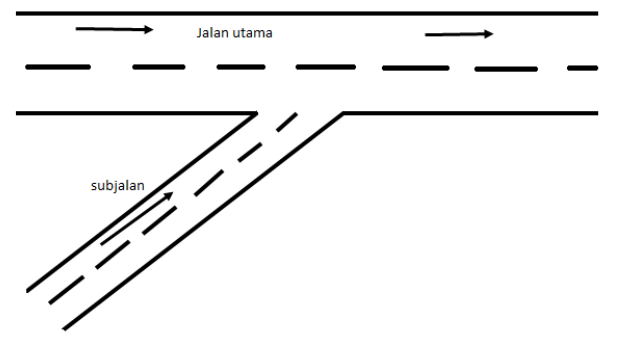

Gambar 1. Ilustrasi jalan merge

Bayangkan situasi di mana pada suatu ruas jalan utama, dan satu bagian jaan ada penggabungan dari gang kecil, separti diilustrasikan pada Gambar 1. Saat volume kendaraan cukup besar pada jalan utama dan ditambah aliran kendaraan dari gang kecil, maka akan terjadi penumpukan kendaraan. Dan kepadatan kendaraan meningkat menimbulkan kemacetan lalu lintas pada jalan utama dan juga di gang kecil tersebut. Merge Scenario merupakan suatu metode pengembangan dari persamaan CTM. Dengan demikian ditunjukkan bahwa scema CTM dapat di modifikasi dengan relatif mudah serta dapat menyimulasikan situasi aliran lalu lintas saat ada penggabungan 2 jalan.

\section{STUdi Terkait}

\section{A. Formula CTM}

Cell Transmission Model adalah suatu metode yang dapat mensimulasikan kondisi lalu lintas di suatu jalan dengan perubahan waktu [3]. Panjang jalan akan dibagi menjadi bagian yang disebut dengan cell yang disimbolkan dengan $i$. Pembagian dari cell bergantung pada panjang jalan, kecepatan kendaraan dan waktu yang dilalui. Cell transmission model juga merupakan suatu metode yang sangat baik dalam mensimulasikan kepadatan arus lalu lintas dengan melihat kendaraan dengan jumlah yang banyak [4]. Formula CTM berawal dari suatu persamaan yang sederhana yaitu dengan mengansumsikan kendaraan berjalan searah dan kondisi lalu lintas yang lancar tidak terjadi gangguan apapun sehingga dapat ditulis persamaannya: 


$$
n_{i+1}(t+1)=n_{i}(t)
$$

Dimana $n_{i}(t)$ adalah jumlah kendaran yang berada pada cell $i$ pada waktu $t$. Penjelasan untuk persamaan (2) ialah di waktu $t+1$, banyaknya kendaraan yang berada pada cell $i+1$ sama dengan banyaknya kendaraan pada cell $i$ saat waktu $t$. Ilustrasinya dapat dilihat pada Gambar 2.

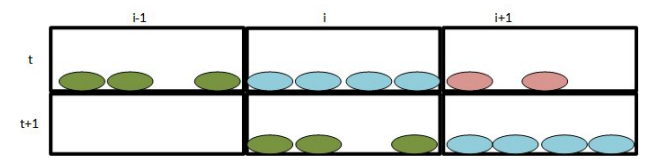

Gambar 2. Ilustrasi persamaan (2).

Namun, persamaan (2) tidak bisa lagi digunakan jika aliran dari kendaraan melebihi kapasitas. Sehingga persamaan (2) perlu dimodifikasi, persamaan yang baru mempunyai dua konstanta penting yaitu $N_{i}(t)$ sebagai jumlah maksimum kendaraan yang berada pada cell $i$ saat waktu $t$, dan $Q_{i}(t)$ sebagai jumlah maksimum kendaran yang mengalir ke cell $i$ pada waktu $t$ menuju $t+1$. Sehingga persamaan (2) akan berubah menjadi:

$$
n_{i}(t+1)=n_{i}(t)+y_{i}(t)-y_{i+1}(t)
$$

Dengan demikian untuk mencari nilai dari jumlah kendaraan yang ada pada cell $i$ pada waktu $t+1$, di perlukan variabel baru yaitu $y_{i}(t)$ yang menyatakan arus yang berhasil pindah pada setiap cellnya.

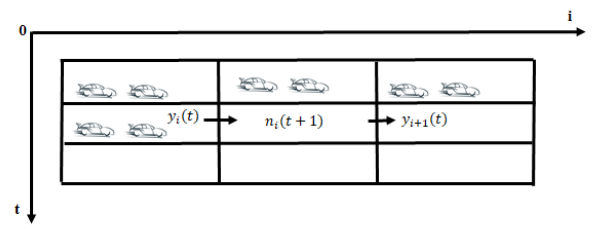

Gambar 3. Ilustrasi persamaan (3).

Ilustrasi dari persamaan (3) dapat dilihat pada Gambar 3. Dan untuk mencari nilai arus pada persamaan (3) dapat dicari dengan:

$$
y_{i}(t)=\min \left[n_{i-1}(t), Q_{i}(t), N_{i}(t)-n_{i}(t)\right]
$$

Dimana, $Q_{i}(t)$ adalah kapasitas arus pada cell $i$ pada interval waktu $t$, dan $N_{i}(t)-n_{i}(t)$ adalah jumlah ruang kosong (tersisa) di cell $i$ pada waktu $t$.

\section{B. Kasus Penggabungan Dua Ruas Jalan (Merge)}

Kemacetan sering muncul dipicu oleh adanya penggabungan/merge dua (atau lebih) laju kendaraan. Merge merupakan suatu keadaan pada suatu ruas jalan raya terdapat penggabungan jalan kecil dengan jalan raya [2].Kasus serupa juga terjadi saat arus kendaraan dari sebuah percabangan jalan masuk ke jalan utama. Pada subbab ini metode CTM yang diuraikan pada bab sebelumnya akan dimodifikasi untuk bisa mengadopsi perhitungan yang melibatkan cell dengan merge.

Gambar 4 mengilustrasikan peristiwa merge tersebut. Cell pada jalan utama (warna kuning) menerima arus kedaraan masuk dari cell dijalan utama (warna hijau) juga dari cell yang berasal dari percabangan jalan (warna abu-abu). 
Agung Ferdiana et. AL.

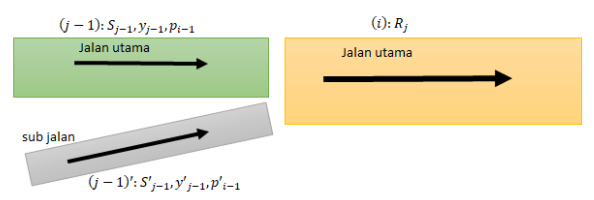

Gambar 4. Ilustrasi jalan merge

1) Formula untuk Merge: Pada subbab ini akan dibahas formula merge. Formula tersebut akan digunakan untuk melengkapi scema CTM agar dapat digunakan untuk menyimulasikan aliran lalu lintas saat ada ruas jalan yang memuat merge.

Mula-mula diperkenalkan notasi-notasi berikut.

- $R_{j}$ sebagai kapasitas dicell $j$;

- $S_{j-1}$ sebagai jumlah kendaraan yang akan dikirim ke cell $j$;

- $y_{j-1}$ sebagai jumlah kendaraan yang berhasil masuk pada cell $j$;

- $p_{j-1}$ sebagai prioritas.

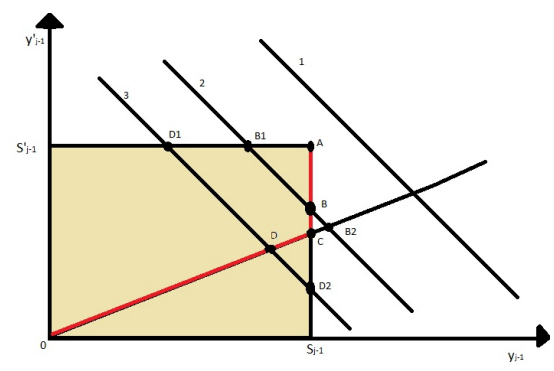

Gambar 5. Situasi saat adanya merge pada suatu ruas jalan

Secara umum terdapat 3 kemungkinan situasi yang akan terjad. Masing-masing kemungkinan tersebut akan dijelaskan pada uraian berikut:

1) Kasus A: Bilamana kapasitas penerima kendaraan lebih besar dari kendaraan yang dikirim.

Dapat dirumuskan dengan $S_{j-1}+S_{j-1}^{\prime} \leq R_{j}$. Untuk garis yang pertama memberikan contoh saat diketahui $S_{j-1}=100, S_{j-1}^{\prime}=80, R_{j}=200$. Dikarenakan kapasitas penampung kendaraan lebih besar dari kedua suply maka dalam garis yang pertama ini tidak terjadi masalah, seperti pada Gambar 5. Solusi yang tempat untuk garis pertama yaitu pada titik A. Dan solusi dapat dirumuskan dengan:

$$
\text { if } R_{j} \geq S_{j-i}+S_{j-1}^{\prime} \text { then }\left\{\begin{array}{l}
y_{j-1}=S_{j-1} \\
y_{j-1}^{\prime}=S_{j-1}^{\prime}
\end{array}\right.
$$

2) Kasus B: Bilamana kendaraan yang dikirim melebihi kapasitas penerima, salah satu jalan padat dengan kendaraan yang akan dikirim.

Dirumuskan dengan $S_{j-1}+S_{j-1}^{\prime}>R_{j}$. Dalam kondisi ini terdapat satu link tidak dapat mengirim semua kendaraan. Untuk contoh $S_{j-1}=100, S_{j-1}^{\prime}=80, R_{j}=160$. Untuk kondisi ini memerlukan prinsip prioritas yang diberikan $p_{j-1} / p_{j-1}^{\prime}=3 / 1$. Garis 2 dapat mewakili pada kondisi saat ini. Pemaparan untuk garis 2 sebagai berikut:

Point B1 dapat dilihat pada Gambar 5 dititik B1 tidak memperdulikan dari aturan prioritas sehingga $S_{j-1}^{\prime}=80$, sehingga jumlah ruang kosong pada penampung menjadi $160-80=80$. Sehingga kendaraan yang ada pada $S_{j-1}$ dapat masuk link $j$ adalah 80 kendaraan dan 20 kendaraan yang tersendat pada $S_{j-1}$.

Point B menunjukan bahwa $S_{j-1}=100$ kendaraan dapat masuk pada link $j$ sehingga jumlah ruang 
kosong yang ada pada link $j 160-100=60$. Maka $S_{j-1}^{\prime}$ hanya dapat mengirim 60 kendaraan dari 80 kendaraan yang ada. Ini merupakan solusi yang benar karena menerapkan prinsip prioritas. Point B2 diberikan link $j$ menerima $160 \times 3 / 4=120$ kendaraan dari $S_{j-1}$ dan sisanya $160-120$ $=40$ ruang kosong yang ada pada link $j$. Sehingga $S_{j-1}^{\prime}$ hanya dapat mengirim 40 kendaraan dari 80 kendaraan kepada link $j$. Dikarenakan pada link $j$ masih tersisa 20 ruang kosong dan pada $S_{j-1}^{\prime}$ tidak dapat mengirimkan kendaraannya lagi maka solusi ini salah. Dapat disimpulakan pada kondisi ini dapat dirumuskan sebagai berikut:

$$
\text { if } R_{j}<S_{j-i}+S_{j-1}^{\prime} \text { then }\left\{\begin{array}{l}
y_{j-1}=\operatorname{mid}\left[S_{j-1}, R_{j}-S_{j-1}^{\prime}, p_{j-1} R_{j}\right] \\
y_{j-1}^{\prime}=\operatorname{mid}\left[S_{j-1}^{\prime}, R_{j}-S_{j-1}, p_{j-1}^{\prime} R_{j}\right]
\end{array}\right.
$$

3) Kasus C: Bilamana kendaraan yang dikirim melebihi kapasitas penerima dan semua jalan padat dengan kendaraan yang akan dikirim.

Diberikan bahwa $S_{j-1}+S_{j-1}^{\prime}>R_{j}$. Untuk kondisi ini terdapat dau link tidak dapat mengirim semua kendaraan yang diwakili dengan garis 3 pada Gambar 5. Contoh $S_{j-1}=100, S_{j-1}^{\prime}=$ $80, R_{j}=120$. Kondisi ini juga menggunakan prinsip prioritas yang diberikan $p_{j-1} / p_{j-1}^{\prime}=3 / 1$. Pemaparan untuk garis 3 sebagai berikut:

Point D1 diberikan $S_{j-1}^{\prime}=80$ kendaraan dari subjalan sehingga pada link $j$ terdapat sisa ruang kosong $120-80=40$. Sehingga pada $S_{j-1}$ hanya dapat mengirimkan 40 kendaraan dari 100 kendaraan, kondisi ini tidak menggunakan prinsip prioritas.

Point D dengan menggunakn prinsip prioritas maka $S_{j-1}$ dapat mengirimkan 120 x $3 / 4=90$ kendaraan dari 100 kendaraan yang harus dikirim ke link $j$. Dengan demikian link $j$ menyisakan ruang kosong sebanyak 120 - $90=30$ kendaraan, sehingga $S_{j-1}^{\prime}$ hanya dapat mengirim 30 kendaraan dari 80 kendaraan. Dan ini merupakan solusi yang benar.

Point D2 diberikan $S_{j-1}$ mengirikan kendaraan kepada link $j$ sebanyak 100 kendaraan. Maka $S_{j-1}^{\prime}$ hanya dapat mengirim 20 kendaraan dari 80 kendaraan. Dan kondisi ini melanggar prinsip prioritas. Sehingga solusi yang benar yaitu pada bagian tengah pada ketiga point yang telah dipaparkan, maka rumusnya sama dengan pada garis ke 2. Dan dapat ditulis rumus penggabungan sebagai berikut:

$$
\begin{aligned}
& \text { if } R_{j} \geq S_{j-i}+S_{j-1}^{\prime} \text { then }\left\{\begin{array}{l}
y_{j-1}=S_{j-1} \\
y_{j-1}^{\prime}=S_{j-1}^{\prime}
\end{array}\right. \\
& \text { if } R_{j}<S_{j-i}+S_{j-1}^{\prime} \text { then }\left\{\begin{array}{l}
y_{j-1}=\operatorname{mid}\left[S_{j-1}, R_{j}-S_{j-1}^{\prime}, p_{j-1} R_{j}\right] \\
y_{j-1}^{\prime}=\operatorname{mid}\left[S_{j-1}^{\prime}, R_{j}-S_{j-1}, p_{j-1}^{\prime} R_{j}\right]
\end{array}\right.
\end{aligned}
$$


Agung Ferdiana et.al.

\section{SiSTEM YANG DibANGUN}

\section{A. Algoritma CTM}

Pada subbab ini akan dijelaskan mengenai algoritma CTM. Algoritma ini akan digunakan untuk menyimulasikan berbagai situasi aliran lalu lintas.

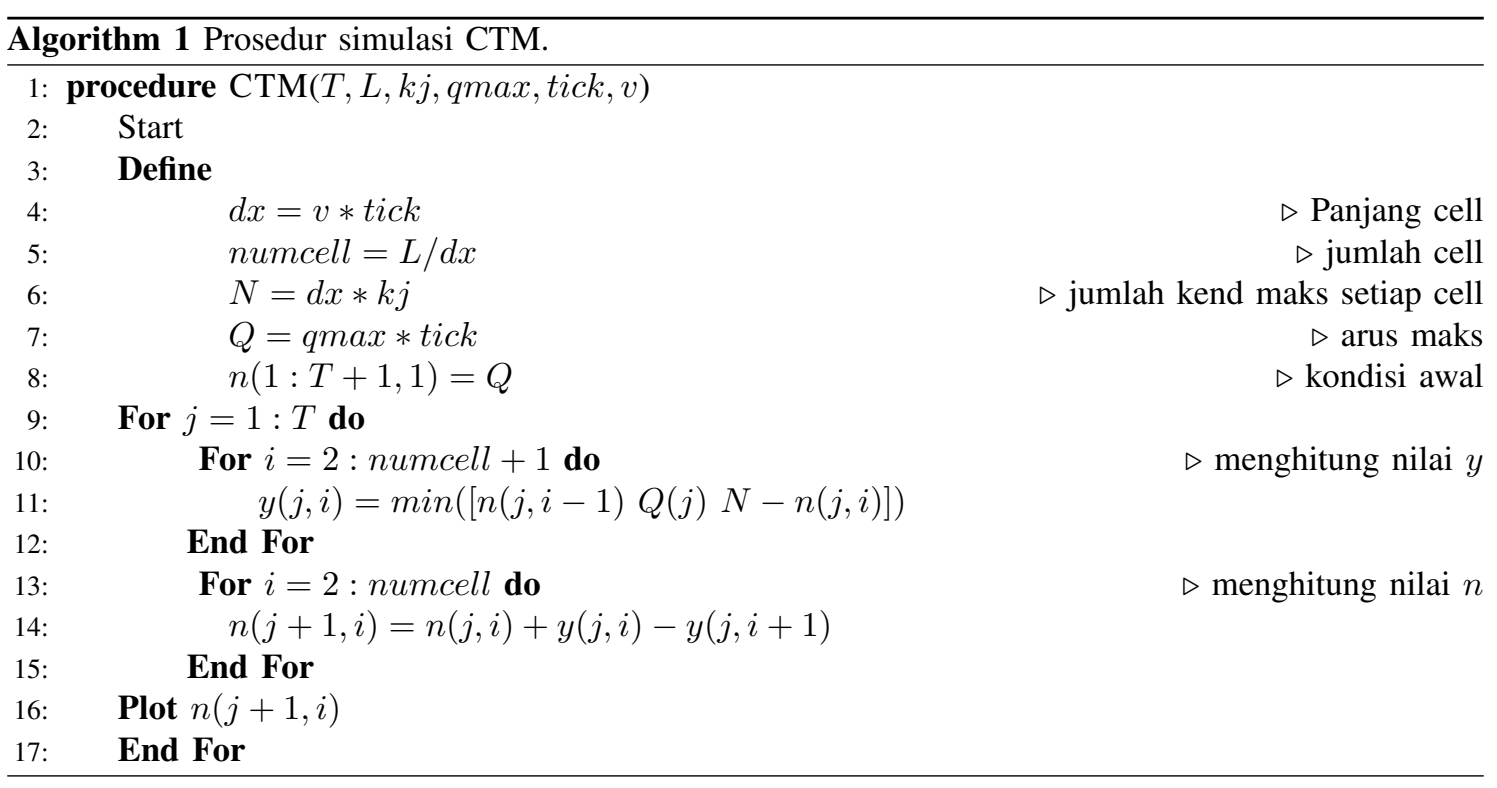

Cara kerja dari algoritma 1, pertama-tama mengisi data dari $\mathrm{T}$ (waktu iterasi), $\mathrm{x}$ (panjang area pengamatan), kj (kepadatan maksimum), qmax (arus maksimum), tick (rentang waktu pengambilan data), v (kecepatan). Setelah mengisi data tersebut tahap selanjutnya, menggunakan data untuk mencari nilai dari $d x$ (panjang cell), numcell (jumlah cell), $\mathrm{N}$ (jumlah maksimum kendaraan untuk setiap cell), Q (arus maksimum untuk setiap cell) dan menginputkan kondisi awal. Langkah selanjutnya mencari nilai $y(j, i)$ untuk setiap cellnya, setelah mendapatkan nilai $y(j, i)$ untuk setiap cell maka tahap terakhir yaitu menghitung nilai dari $n(j+1, i)$ dan plot solusi CTM.

\section{Hasil Dan PEMbahasan}

A. contoh CTM

1) Contoh pertama, pengamatan dilakukan pada suatu ruas jalan yang penjangnya $1.25 \mathrm{~km}$, setiap kendaraan yang melintas pada jalan tersebut dapat melaju dengan kecepatan $50 \mathrm{~km} / \mathrm{jam}$, dengan kepadatan maksimum 180 kendaraan $/ \mathrm{km}$. Pada area pengamatan tersebut arus maksimumnya 3000 kendaraan/jam. Pengamatan dilakukan setiap 6 detik sekali. Pada saat awal arus kendaraan yang lewat sebanyak $80 \%(q=2400$ kendaraan $)$ dari kapasitas arus maksimum. Pada contoh ini area pengamatan tidak terdapat gangguan sehingga kendaraan dapat melaju tanpa adanya hambatan. 


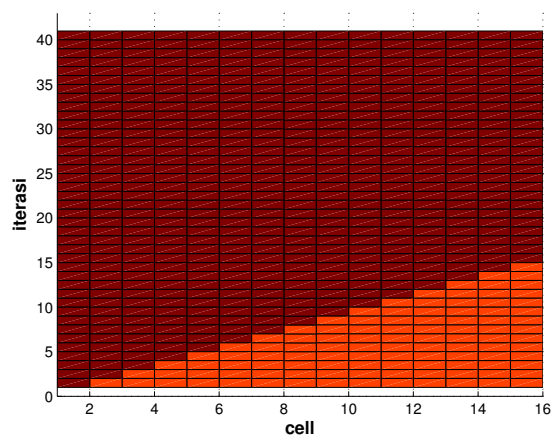

Gambar 6. Keadaan area pengamatan tidak terjadi hambatan.

Gambar 6 menampilkan hasil sumulasi dari contoh 1. Dapat diamati bahwa pada contoh pertama tidak terdapat gangguan pada area pengamatan sehingga warna merah menunjukan ada 5 kendaraan yang berada pada cell tersebut dan warna orange ada 4 kendaraan. Sehingga selama waktu interasi yaitu 40 second tidak terjadi banyak perubahan jumlah kendaraan, disebabkan karena nilai arus maksimum pada setiap cell (Q) tidak berubah yaitu 5 kendaraan.

2) Contoh kedua, pengamatan dilakukan pada suatu jalan yang penjangnya $1.25 \mathrm{~km}$, dengan kepadatan maksimum 180 kendaraan $/ \mathrm{km}$. Pada area pengamatan tersebut arus maksimumnya 3000 kendaraan/jam. Setiap kendaraan yang melintas pada jalan tersebut dapat melaju dengan kecepatan $50 \mathrm{~km} / \mathrm{jam}$. Dalam pengamatan ini data diambil setiap 30 detik sekali. Saat awal, pada area pengamatan tidak terdapat gangguan sehingga kendaraan dapat melaju tanpa adanya hambatan. Saat awal arus kendaraan yang lewat sebanyak 80\% $(q=2400$ kendaraan $)$ dari kapasitas arus maksimum. Akan tetapi, pada 1/3 dari ujung jalan terjadi penyempitan jalan yang mana berlangsung selama 2 menit. Di lokasi penyempitan arus kendaraan yang lewat hanya 20\% $(q=600$ kendaraan $)$ dari arus maksimum.

Tabel I

KONDISI AWAL SAAT T $=1$ SEBELUM TERJADI PENYEMPITAN.

\begin{tabular}{|c|c|c|c|c|c|c|}
\hline & gate 0 & cell 1 & cell 2 & cell 3 & cell 4 & \\
\hline $\mathrm{Q}$ & & 25 & 25 & & 25 & \\
\hline $\mathbf{N}$ & & 75 & 75 & 75 & 999 & \\
\hline Iterasi & & & & & & Q3 \\
\hline 1 & 20 & 20 & 20 & 20 & & 5 \\
\hline 2 & 20 & & & & & 5 \\
\hline 3 & 20 & & & & & 5 \\
\hline 4 & 20 & & & & & 5 \\
\hline 5 & 20 & & & & & 25 \\
\hline 6 & 20 & & & & & 25 \\
\hline 7 & 20 & & & & & 25 \\
\hline 8 & 20 & & & & & 25 \\
\hline 9 & 20 & & & & & 25 \\
\hline 10 & 20 & & & & & 25 \\
\hline 11 & 20 & & & & & 25 \\
\hline 12 & 20 & & & & & 25 \\
\hline 13 & 20 & & & & & 25 \\
\hline 14 & 20 & & & & & 25 \\
\hline 15 & 20 & & & & & 25 \\
\hline 16 & 20 & & & & & 25 \\
\hline 17 & 20 & & & & & 25 \\
\hline 18 & 20 & & & & & 25 \\
\hline
\end{tabular}


Agung Ferdiana et.al.

Simulasi berbagai Situasi Traffic...

Tabel II

HASIL SIMULASI PENYEMPITAN JALAN DENGAN PENGAMBILAN DATA 30 DETIK SEKALI.

\begin{tabular}{|c|c|c|c|c|c|c|}
\hline & gate 0 & cell 1 & cell 2 & cell 3 & cell 4 & \\
\hline $\mathrm{Q}$ & & 25 & 25 & & 25 & \\
\hline $\mathrm{N}$ & & 75 & 75 & 75 & 999 & \\
\hline Iterasi & & & & & & $\mathrm{Q} 3$ \\
\hline 1 & 20 & 20 & 20 & 20 & & 5 \\
\hline 2 & 20 & 20 & 35 & 5 & & 5 \\
\hline 3 & 20 & 20 & 50 & 5 & & 5 \\
\hline 4 & 20 & 20 & 65 & 5 & & 5 \\
\hline 5 & 20 & 30 & 70 & 5 & & 25 \\
\hline 6 & 20 & 45 & 50 & 25 & & 25 \\
\hline 7 & 20 & 40 & 50 & 25 & & 25 \\
\hline 8 & 20 & 35 & 50 & 25 & & 25 \\
\hline 9 & 20 & 30 & 50 & 25 & & 25 \\
\hline 10 & 20 & 25 & 50 & 25 & & 25 \\
\hline 11 & 20 & 20 & 50 & 25 & & 25 \\
\hline 12 & 20 & 20 & 45 & 25 & & 25 \\
\hline 13 & 20 & 20 & 40 & 25 & & 25 \\
\hline 14 & 20 & 20 & 35 & 25 & & 25 \\
\hline 15 & 20 & 20 & 30 & 25 & & 25 \\
\hline 16 & 20 & 20 & 25 & 25 & & 25 \\
\hline 17 & 20 & 20 & 20 & 25 & & 25 \\
\hline 18 & 20 & 20 & 20 & 20 & & 25 \\
\hline & & & & & & \\
\hline
\end{tabular}

Tabel II menampilkan hasil simulasi saat terjadi penyempitan jalan pada cell 3. Tampak bahwa sebagai akibat dari penyempitan tersebut maka volume kendaraan pada cell 2 dan cell 1 bertambah. Penyempitan hanya terjadi selama 2 menit. Sesudah 2 menit, nilai fluks pada cell tersebut kembali normal yaitu 25 kendaraan. Hasil simulasi menunjukkan bahwa mulai dari iterasi ke 6, tampak bahwa kepadatan kendaraan pada cell 2 dan cell 1 mulai terurai. Hal ini disebabkan karena fluks di cell 3 kembali normal.

Saat iterasi ke 18 banyaknya kendaraan tiap cell sudah kembali normal, ini berarti efek penyempitan yang terjadi selama 2 menit sudah tidak terasa efeknya, atau aliran kendaraan sudah kembali normal.

3) Contoh ketiga, untuk contoh ini hampir sama dengan dengan contoh 2. Perbedaannya pada rentang waktu pengambilan data, pada contoh ini pengambilan data setiap 6 detik sekali. Sehingga hasil simulasi dapat dilihat pada Gambar 3.

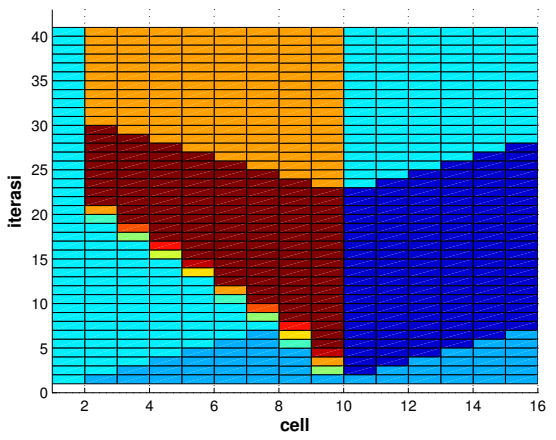

Gambar 3 menampilkan adanya penyempitan jalan yang terjadi pada cell 10. Dengan kondisi awal arus maksimum pada setiap cell (Q) adalah 5 kendaraan kecuali pada cell 10 arus maksimumnya 1 kendaraan dan untuk setiap cell hanya dapat menampung 15 kendaraaan. Pada cell 9 dengan berjalannya waktu volume kendaraan semakin bertambah hampir mencapai jumlah batas maksimum kendaraan pada setiap cellnya. Warna merah menunjukan ada 14 kendaraan yang ada pada cell tersebut, warna kuning menunjukan ada 10 kendaraan, warna biru muda menunjukan ada 5 kendaraan dan warna biru menunjukan ada 1 kendaraan pada cell tersebut. Saat mulai terjadinya penyempitan jalan pada cell 10 selama 2 menit, akan mengakibatkan penumpukan kendaraan pada cell 2 sampai 
cell 9. Akan tetapi, untuk cell 11 sampai cell 15 akan terjadi kelonggaraan kendaraan. Setelah 2 menit kepadatan kendaraan pada cell 1 sampai cell 9 akan mulai terurai, hal tersebut diakibatkan karena arus maksimum pada cell 10 kembali normal yaitu 5 kendaraan yang sebelumnya hanya 1 kendaraan saja.

4) Contoh keempat, pada area pengamatan terjadi sumbatan pada $1 / 3$ dari ujung jalan yang berlangsung selama 2 menit. Sehingga pada waktu tersebut kendaraan tidak dapat melewati pada titik yang terjadai sumbatan tersebut. Maka perubahan lalu lintas pada area pengamatan tersebut.

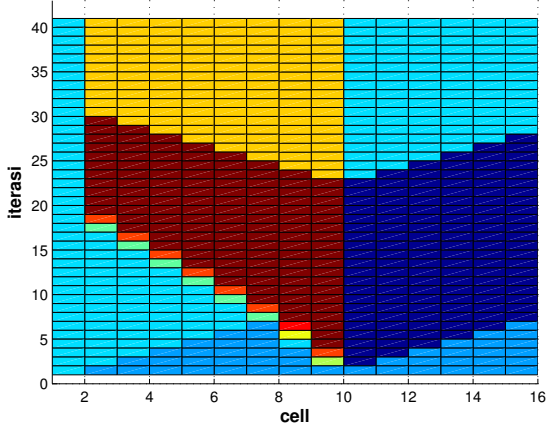

Gambar 7. Keadaan area pengamatan saat terjadi sumbatan jalan.

Gambar 7 menunjukan hasil simulasi terjadinya sumbatan pada jalan di cell 10. Untuk setiap cell hanya dapat menampung maksimum 15 kendaraan. Penyumbatan pada cell 10 berarti bahwa tidak ada kendaraan yang dapat melewati cell 10 atau arus maksimum pada cell 10 adalah 0 dan penyumbatan terjadi selama 2 menit. Sumbatan tersebut mengakibatkan volume kendaraaan akan bertambah pada cell 2 sampai cell 9 mencapai batas maksimum dari daya tampung setiap cell. Akan tetapi, untuk cell 10 sampai cell 15 volume kendaraan akan mencapai 0 selama penyumbatan terjadi. Setelah 2 menit kendaraan mulai terurai dikarenakan fluks pada cell 10 sudah mulai kembali normal. Untuk contoh 3 saat terjadi penyumbatan, kendaraan yang berada pada cell 2 sampai cell 9 terdapat bergerak sama sekali. berbeda dengan contoh 3 kendaraan yang berada pada cell 2 sampai cell 9 masih bisa bergerak walau hanya 1 kendaraan yang bisa berpindah ke cell yang ada didepannya selama terjadi penyempitan jalan.

\section{B. Simulasi kasus Merge}

1) Simulasi pertama untuk kasus merge akan diuraikan disini. Perhatikan suatu ruas jalan yang penjangnya $1.25 \mathrm{~km}$, setiap kendaraan yang melintas pada jalan tersebut dapat melaju dengan kecepatan $50 \mathrm{~km} / \mathrm{jam}$, dengan kepadatan maksimum 180 kendaraan $/ \mathrm{km}$, pada area pengamatan arus maksimum yaitu 3000 kendaraan/jam, dalam pengamatan ini pengambilan data setiap 6 detik sekali. Saat awal arus kendaraan yang lewat sebanyak 80\% ( $q=2400$ kendaraan $)$ dari kapasitas arus maksimum. Akan tetapi terdapat sejumlah kendaraan yang masuk dari jalan kecil yang bertepatan pada $1 / 3$ dari ujung jalan. Kepadatan kendaraan pada jalan kecil yang akan masuk kejalan utama mencapai $86 \%$ dari kapasitas maksimumnya dari jalan raya tersebut. 
Agung Ferdiana et.al.

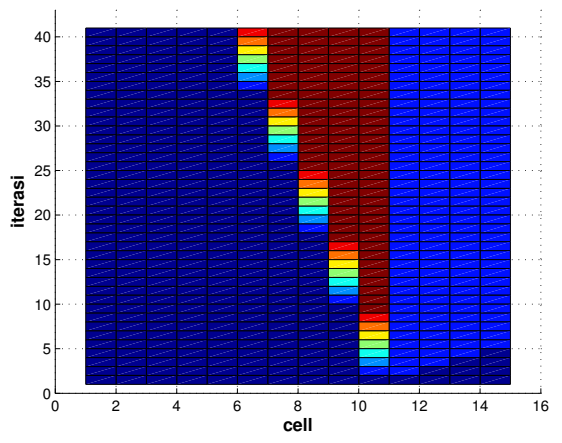

Gambar 8. Hasil kasus merge scenario.

Gambar 8 menampilkan hasil simulasi dimana pada cell 10 penggabungan/merge. Hasil simulasi menunjukan adanya penggabungan di cell 10, antrian kendaraan meningkat pada cell 10 sampai cell 6. Sampai iterasi ke 40 tumpukan padat kendaraan hanya terjadi pada cell 6 sampai cell 10. Itu dikarenakan adanya kendaraan yang masuk ke jalan utama dari jalan kecil sebesar 86\% dari kapasitas penampung. Cell 6 sampai cell 10 tidak mencapai nilai maksimum dari kapasitas pada setiap cell karena sejumlah kendaraan masih dapat melewati titik penggabungan/merge sebanyak 5 kendaraan pada setiap iterasi.

2) Kasus kedua merge, pengamatan dilakukan pada suatu jalan yang penjangnya $1.25 \mathrm{~km}$, setiap kendaraan yang melintas pada jalan tersebut dapat melaju dengan kecepatan $50 \mathrm{~km} / \mathrm{jam}$, dengan kepadatan maksimum 180 kendaraan $/ \mathrm{km}$, pada area pengamatan arus maksimum yaitu 3000 kendaraan/jam, saat pengamatan pengambilan data setiap 6 detik sekali. Pada saat awal arus kendaraan yang lewat sebanyak 100\% dari kapasitas arus maksimum. Penggabungan/merge terjadi pada 1/3 dari ujung jalan. Kepadatan kendaraan pada jalan kecil yang akan masuk kejalan utama mencapai $27 \%$ dari kapasitas penampung kendaraan pada jalan utama.

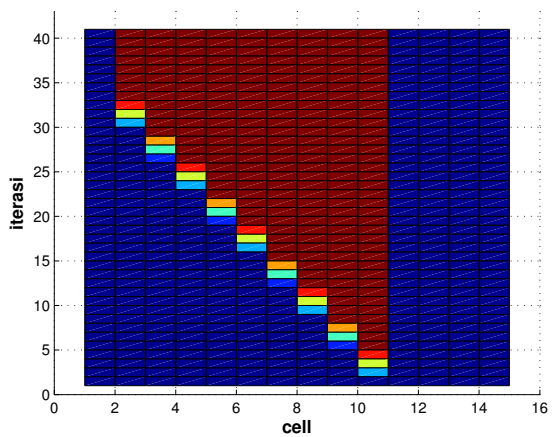

Gambar 9. Hasil contoh dua merge scenario.

Gambar 9 menampilkan hasil penggabungan/merge saat kondisi jalan utama padat dan jalan kecil juga padat. Kondisi awal jalan utama jumlah kendaraan yang melintas yaitu 5 kendaraan untuk jalan kecil 4 kendaraan. Untuk contoh yang kedua penumpukan kendaraan terjadi pada cell 2 sampai cell 10. Akan tetapi cell 11 sampai cell 15 volume kendaraan yang melintas normal, karena pada cell tersebut tidak terpengaruhi adanya merge pada cell 10. Perbedaan dari contoh yang pertama yaitu jumlah cell yang terpengaruhi akibat penggabungan/merge tersebut. Untuk contoh pertama cell yang terdapat penumpukan kendaraan hanya cell 6 sampai cell 10. Namun, pada contoh kedua penumpukan kendaraan terjadi kepada semua cell yang ada dibelakang cell 10. 


\section{Kesimpulan}

Metode CTM telah berhasil diterapkan untuk menyimulasikan aliran lalu lintas dalam berbagai kondisi. Metode CTM relatif mudah atau sederhana, dan telah dapat mempresentasikan berbagai situasi real kemacetan lalu lintas pada jalan raya. Terdapat 2 parameter yang sangat berpengaruh metode CTM adalah Q (arus maksimum untuk setiap cell) dan N (kapasitas untuk setiap cell). Dalam hal suatu ruas jalan memuat bagian dengan merge, modifikasi CTM telah berhasil menyimulasikan situasi kemacetan pada jalan yang terdapat penggabungan 2 jalan dan hasilnya sesuai seperti yang sering kita temui sehari-hari.

\section{ACKNOWLEDGMENT}

Penulis berterimakasih kepada Prof. Sri Redjeki Pudjaprasetya, atas masukan dan bantuannya selama pengerjaan penelitian ini.

\section{PUSTAKA}

[1] Ali Alhadar. Analisis kinerja jalan dalam upaya mengatasi kemacetan lalu lintas pada ruas simpang bersinyal di kota palu. SMARTek, 9(4), 2011.

[2] Peter Hidas. Modelling vehicle interactions in microscopic simulation of merging and weaving. Transportation Research Part C: Emerging Technologies, 13(1):37-62, 2005.

[3] Tom V Mathew. Fuel consumption and emission studies. Transportation Systems Engineering, IIT Bombay, 2014.

[4] Laura Muñoz, Xiaotian Sun, Roberto Horowitz, and Luis Alvarez. Traffic density estimation with the cell transmission model. In American Control Conference, 2003. Proceedings of the 2003, volume 5, pages 3750-3755. IEEE, 2003.

[5] Daiheng Ni. Traffic Flow Theory: Characteristics, Experimental Methods, and Numerical Techniques. Butterworth-Heinemann, 2015

[6] Badan Pusat Statistik. Statistical yearbook of indonesia. Badan Pusat Statistik, Jakarta, Indonesia, 1995.

[7] Ria Susiliawati. Mathematical review of the macroscopic and microscopic models of traffic flow. 2009.

[8] Tulus Tambunan. Kondisi infrastruktur di indonesia. Kadin Indonesia-Jetro, 2006.

[9] Ofyar Z Tamin. Pemecahan kemacetan lalu lintas kota besar. Journal of Regional and City Planning, 3(4):10-17, 1992. 
